\title{
THE ROLES OF ICT IN CULTIVATING THE CHARACTER OF ELEMENTARY SCHOOL STUDENTS
}

\author{
Octavia Widiastuti, Agus Soleh, Teguh Sulistyo \\ Faculty of Language and Literature, Universitas Kanjuruhan Malang, \\ teguhsulistyo30@yahoo.co.id
}

Diterima: 09-12-2017

Direview: 02-05-2018

Diterbitkan: 27-07-2018

Hak Cipta @ 2017 oleh Penulis (dkk.) dan Jurnal Sosial Humaniora (JSH)

*This work is licensed under the Creative

Commons Attribution International License (CC

BY 4.0).

http://creativecommons.org/licenses/by/4.0/
Subject Areas: Education

\begin{abstract}
The use of Information and Communication Technology (ICT) in all levels of education has been implemented broadly for years. This paper aims at reporting the power of ICT in cultivating elementary school students' character. The recent study, basically, is twofold: First, to find out elementary school students' perceptions towards the use of ICT in the form of short videos and Hot Potatoes in the classrooms; second, to investigate the positive character of the students appearing during the implementation of ICT. There were 45 fifth graders of an elementary school joining the project. They were treated using ICT in the classroom, and they were encouraged to express their opinion dealing with the use of ICT in the classroom. The findings of the present study suggest that teachers should facilitate their students with ICT for it is necessary to build positive student character, and it motivates them to be more curious in the teaching and learning process.
\end{abstract}

Keywords: ICT; short videos; hot potatoes; character education

\section{Background of The Study}

Indonesia is considered as a Country having suave inhabitants. Nevertheless, the multidimensional crisis in 1998 led this country into a very bad condition. One such parameter is that the poor character of its people. Chotimah (2011) states that the crisis has resulted in the decreased self-confidence and self-esteem of Indonesian young persons. The youth easily get any kind of information without filtering wisely the information they have got. The fast spread of the use of Information and Communication Technology (ICT) enables them to access the world, especially via internets such as YouTube and television. Thus, it is important to protect them to behave in negative manners and empower them to cultivate good character.
Basically, the term 'character' simply means attitude or behavior. A man having good character is the one who is empowered with good behaviors. Thus, the act of empowering children with good character must be done through character education. The term c character education' began popular in the 1900's when Thomas Lickona introduced his books entitled The Return of Character Education and Educating for Character: How Our School Can Teach Respect and Responsibility. Kamaruddin (2012) says that character education is not only a matter of teaching what is right and what is wrong to children, but it inculcates the habit (habituation) of the good which children understand, able to feel, and want to do good. Almerico (2014) describes character education as an effort to teach children about essential traits needed to 
cultivate good character. It deals with teaching children to develop the awareness to behave in an appropriate manner in different social contexts. Thus, the outcomes of character education are good attitudes students must apply in the society in different contexts.

Some experts in character education have proposed different contents of character which students need to have. Bialik et al. (2015) believe that in school, practices dealing with the character may feature some contents such as growth mindset, stages of moral development, systems - awareness, internships, global cause involvement, etc. Almerico (2014) state that character education concepts are taught within the context of literature to educate students aspects of life such as respect, honesty, courage, and kindness. Meanwhile, Kemendiknas (2011) formulates 18 character children need to pose in their daily lives based on religion, Pancasila, culture, and the goals of national education as follows: (1) religious, (2) honest, (3) tolerant, (4) discipline, (5) hard-working, (6) creative, (7) independent, (8) democratic, (9) curious, (10) nationalistic, (11) loving, (12) respectful, (13) communicative, (14) peaceable, (15) fond of reading, (16) caring, (17) sociable, and (18) responsible. Ainiyah (2013) adds that the indicators of the success of character education deal with three aspects: knowing the good (cognitive), loving the good (affective), and acting the good (psychomotor).

Experts believe that the ages of $0-10$ are golden moments to build one's character. The necessity to build their character is absolutely needed to prepare good young generations. At those ages, elementary school students at the age of $6-12$ need to be treated wisely. Thus, education is an answer to prepare them to be good citizens with the positive character in the future. Besides, elementary school students enjoy games and ICT. Thus the two things must be combined in order to maximize the outcomes of education, including character building of the students.

The use of ICT in all levels of education has been employed broadly for years. Somehow, some people believe that ICT only deals with 'computers and computing related works' (Amin, 2013). On the other hand, UNESCO (2002) clarifies that ICT is the combination of 'informatics technology' with other related to technology, especially communication technology. ICT, with regards to the character building of elementary school students, refers to the use of general components of information and communication technologies in the classrooms. Lavin, Korte, and Davies (2012) argue that ICT in classrooms has broadly been implemented since students have positively become tech-savvy literate, and it has been applied in the classrooms for the last 30 years when Computer-Assisted Language Learning (CALL) was developed and implemented in the fields of education (Domalewska, 2014). However, more specifically ICT, in this context, refers to the use of Hot Potatoes and short videos used by teachers as a learning tool for students.

The roles of ICT in education, according to Amin (2013), can increase the flexibility in delivering education, so learners can access knowledge anytime and anywhere. Furthermore, Chamorro and Rey (2013) claim that the use of ICT may cultivate students' personal and professional lives, and successful communication learning relies on the students' desire to participate.

Some experts and researchers have been investigating the use of ICT in the classrooms, yet the facts show that there have been a few studies examining the roles of ICT in cultivating the character 
of elementary school students. A study by Kamarudin (2012) investigating character education and student social behavior found that character education is important for the growth of an individual and should be done very early. Another study by Abu et al. (2015) trying to analyze character education of the students revealed that the failure of the teachers in establishing the student character through 'Kantin Kejujuran' was caused by the fact showing that the program suffered from losses and bankruptcies without any effort to stand back up. Chamorro and Rey (2013) revealed that the use of technology-based activities in the classroom is twofold: reinforcing already studied topics in class and promoting motivation. Accordingly, ICT seems meaningful in the classroom, yet how students behave towards ICT should be investigated further, especially their attitudes and expectations during the class.

The findings of the previous research, indeed, show different results and even contrary. Thus it is still necessary to examine further the roles of ICT in cultivating student character. Let alone, the present study tries to examine how the characteristics of young learners, especially elementary school students behave towards the use of ICT in cultivating their good character.

This paper then tries to investigate the impacts of ICT on elementary school student perceptions towards the implementation of ICT and the characters appearing in the classroom. As a result, the research questions were formulated as follows:

1. What are the perceptions of the elementary students towards the use of ICT in stimulating their character?
2. What kinds of character appeared during the implementations of ICT?

\section{Methods}

The present study used qualitative methods, based on classroom and school since it aimed at investigating qualitatively the elementary students' perceptions towards the use of ICT and kinds of a character appearing during the implementation of ICT, specifically Hot Potatoes and short educational videos in the classroom. The present study was conducted at SDN (State Elementary School) Tanjung Sekar 3 Malang, East Java. A total of 45 elementary school students of the fifth grade took place actively in the research. In addition, a teacher was also involved, too. The students were treated using Hot Potatoes and short educational videos in order to examine kinds of character they performed. Thus, an observation sheet, fieldnotes, and interview were administered to collect the data needed dealing with students' perceptions towards the implementation of ICT and kinds of a character appearing during the intervention. The observation sheet was used by the researchers to get data related to the students' activities and character appearing during the intervention. The fieldnotes were applied to the atmosphere of the class. Last, the interview was conducted after the implementation of ICT with the class teacher and 5 students representing the class. The present study follows the steps in Figure 1. 
Figure 1

ICT in Character Education

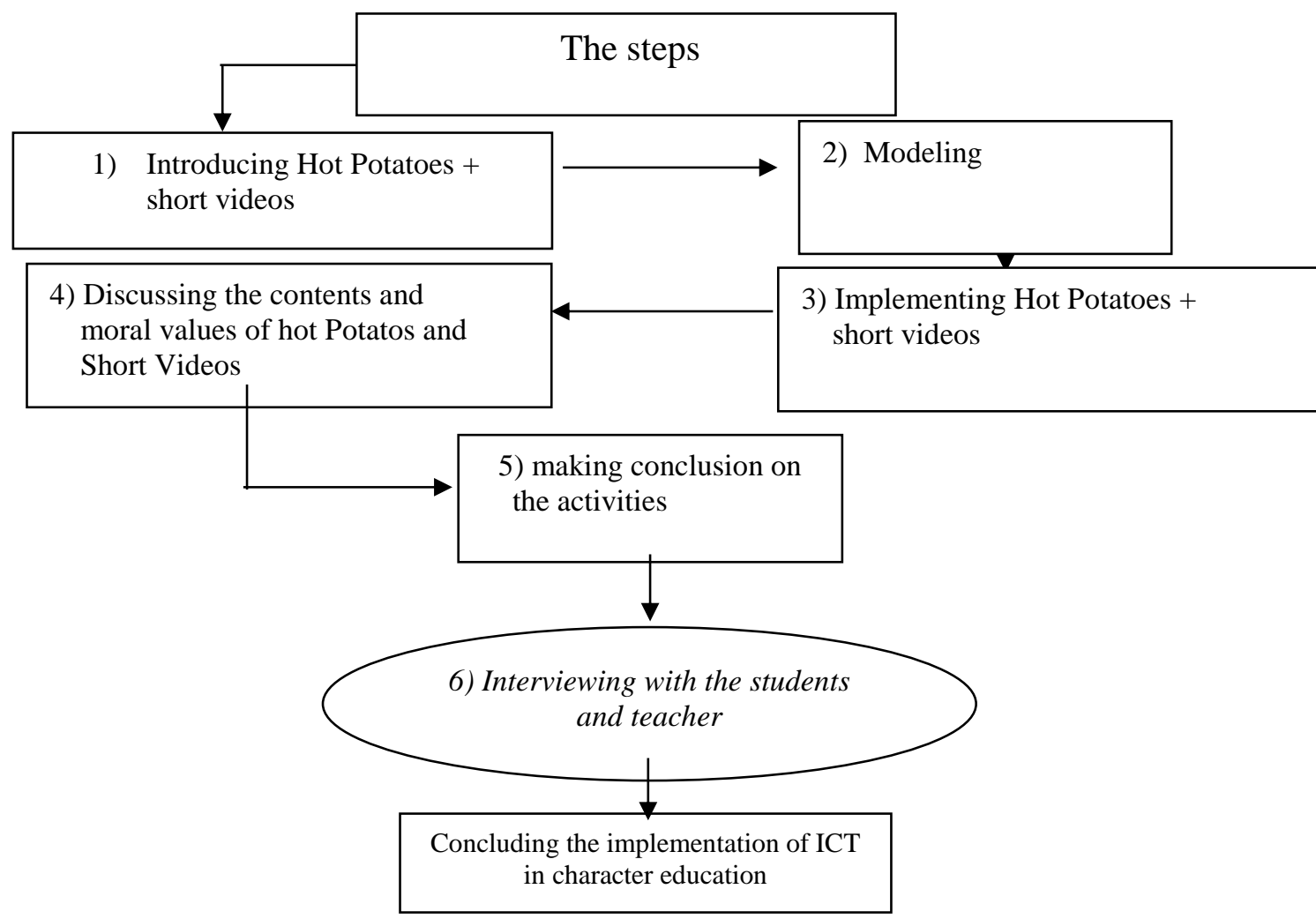

\section{Findings And Discussion}

The data were collected from an interview with the students after the implementation of ICT in the classroom and with the teacher after the implementation of the model (see Figure 1). In addition, fieldnotes and observation were also administered to observe the students' character during the interventions. Implementing ICT, the teacher-researcher also collected the students' perceptions towards ICT by asking the class directly related to what they felt about Hot Potatoes and short videos, while another researcher observed the class and examined students' character.

\section{Student Perceptions Towards The Use Of ICT In}

\section{The Classroom}

The first question of the present paper deals with the perceptions of the elementary students towards the use of ICT in stimulating their character. Answering the question, the students had different ideas, but in general, they expressed positive perceptions. When the teacher-researcher was introducing Hot Potatoes, the students looked motivated to understand more not only the content but also the program. In this case, the researcher did not focus on the ability of the students in completing the task but how they performed in joining the class. It is in line with the findings of a study conducted by Guerza (2015) which claims that ICT pedagogies could cultivate positive opportunities for learners to engage in the teaching-learning process. Miyazoe 
and Anderson (2010) also revealed that the motivation of the students increases when they are treated using ICT. Lin, Groom, and Lin (2013) state that ICT is now widely regarded as having potentials for enhancing the teaching-learning process. Domalewska (2014) also adds that ICT promotes the students in the learning process modifying the way learning takes place.

The students looked enthusiastic when being treated using the short cartoon videos. They not only discussed the contents of the videos but also the moral values with the guidance of the teacher. It was very easy for them to express what they felt about the characters in the videos since the contents were very close to them. For instance, being given a short video about 'Three Pigs', the students discussed the contents and moral values happily. With the guidance of the teacher, they expressed their ideas as follows: Teacher: What do you think of the three pigs?

Student 1: They have different characteristics. The first and second pigs are lazy. They only play and play.

Student 2: I like the third pig. He is diligent and built a strong house to live in.

Teacher: So, what happened to them?

Student 3: The first and the second pig suffered from the attack of a wolf. But the third pig could protect himself from the wolf and helped the other two pigs to live with him.

Teacher: That's great.

The discussion helped the students understand why people need to work hard and help each other. In other words, the video stimulates the students to learn better. Meanwhile, some students expressed what they felt during the intervention such as:

- Amazing. It is just like playing and playing

- I Wanna watch more videos

- Funny stories

- I need to understand Hot Potatoes more

- $\quad$ Learning while playing
- Etc.

The comments show that they have positive perceptions towards the implementation of ICT in the classroom. Besides, they have more motivation in learning since one of the characteristics of young learners is that they will be productive if the class is conducted while playing.

\section{Character Appearing In The Classroom}

The kinds of character observed were based on those proposed by Kemendiknas (2011). Among the 18 kinds, the present research only focuses on the most dominant kinds of a character appearing in the classroom. They are as follows:

- Hard working (eg. Finding out moral values and accomplishing the tasks)

- Democratic (eg. They give a chance to their classmates to speak up)

- Curious (eg. They want to watch more similar videos and their classmates' ideas)

- Respectful (eg. Giving respects to their classmates when having different ideas or answers)

- Sociable (eg. Showing sympathy to unlucky characters in the videos)

- Disciplined (eg. Obeying the rules of learning)

- Communicative (eg. Having good communication with their classmates and teacher)

- Responsible (eg. Accomplishing their tasks)

- Honest (eg. Expressing ideas based on the contents of videos by avoiding like and dislike)

- Tolerant (eg. Understanding that others may have different perspectives) 
- Religious (eg. Believing in God and the good will win in the end)

The kinds of the character above appeared in the classroom during the intervention. Somehow, according to Ainiyah (2013), the real success of character education deal with three aspects: knowing the good (cognitive), loving the good (affective), and acting the good (psychomotor). It shows that the success of character education takes times if the students can apply the kinds of character in the society. So, Schools have an important role to play in the development of children's social and emotional growth (Almerico,2014).

\section{Conclusions and Suggestions}

The results of the study revealed that ICT motivates the students to enjoy the class. Sulistyo (2016) also proved that teaching and learning process in integration with ICT allows the students to be more motivated in the classroom, and the class becomes more interesting (Miyazo and Anderson, 2010). Besides, the students looked more enthusiastic to learn more since ICT leads the class to be more varied and interesting. For them, the class looks like learning while playing or vice versa. ICT also makes them more curious in the teaching and learning process. In short, they have positive perceptions towards the implementation of ICT in the classroom.

In addition, ICT stimulates students to build their positive character. Some dominant kinds of the character appeared are hard-working, democratic, curious, respectful, sociable, disciplined, communicative, responsible, honest, tolerant, and religious. Somehow, the character will be useless if the students do not apply them in the society well. In other words, the success of character education happens if the students have three aspects: knowing the good (cognitive), loving the good (affective), and acting the good (psychomotor). Thus, schools have to be responsible to play their roles to build students' positive character.

This study, of course, has some limitations such as a small number of elementary students involved and limited time to apply ICT, so it is suggested that more researchers conduct better comprehensible studies in order to provide better new insights related to character education for children.

\section{Bibliografi}

Abu, L., Mokhtar, M., Hassan, Z, and Suhan, S.Z.D. 2015. How to Develop Character education of Madrassa Students in Indonesia. Journal of Education and Learning. Vol. 9 (1), 7986.

Ainiyah, N. 2013. Pembentukan Karakter Melalui Pendidikan Agama Islam. Jurnal Al-Ulam, Vol. 13 (1), 25-38.

Almerico, G.M. 2014. Building Character through Literacy with Childrens' Literature. Research in Higher Education Journal. Vol. 26, 1 - 13.

Amin, S.N. 2013. An Effective Use of ICT for education and Learning by Drawing on Worldwide Knowledge, Research, and Experience: ICT as a Change Agent for Education.

http://www.nyu.edu/classes/keefer/waoe/ amins.pdf. Retrieved January 10, 2016.

Bialik, M., Bogan, M., Fadel, C., and Harvathova, M. 2015. Character Education for $21^{\text {st }}$ Century: What Should Students Learn? Boston: Montes Alti Educational Foundation.

Chamorro, M.G. \& Rey, L. 2013. Teachers' beliefs and the Integration of Technology in the EFL Class. HOW, A Colombian Journal for Teachers of English. Vol. 20. 51-72.

Chotimah, U. 2011. Membangun Karakter Peserta didik Melalui Penerapan Beberapa Alternatif Pendekatan Pembelajaran. Makalah Disampaikan dalam Kegiatan Seminar Nasional Pendidikan yang Diselengggarakan di Palembang 7 Mei 2011.

Domalewska, D. 2014. Technology-Supported Classroom for Collaborative Learning: Blogging in the Foreign Language 
Classroom. International Journal of Education and Development using Information and Communication Technology (IJEDICT), 10 (4), 21-30.

Guerza, R. 2015. ICT in the Algerian EFL Classrooms: An Innovative Means to Enhance Learners' Autonomy. International Journal for Infonomics (IJI), Volume 8, Issue 1.

Kamaruddin, S.A. 2012. Character Education and Students Social Behavior. Journal of Education and Learning. Vol. 6 (4), 223230.

Kemendiknas. 2011. Pedoman Pelaksanaan Pendidikan Karakter (Berdasarkan Pengalaman di Satuan Pendidikan Rintisan). Jakarta. Balitbang Pusat Kurikulum dan Perbukuan.

Lavin, A.M., Korte, L., \& Davies, T.L. 2012. The Impact of Classroom Technology on Student Behaviour. Journal of Technology Research.

Lin, M.H., Groom, N., \& Lin, C.Y. 2013. BlogAssisted Language Learning in the ESL Writing Classroom: A Phenomenological Analysis. Educational Technology \& Society, 16 (3), 130-139.

Miyazoe, T. \& Anderson, T. 2010. Learning Outcomes and Students' Perceptions of Online Writing: Simultaneous Implementation of a Forum, Blog, and Wiki in an EFL Blended Learning Setting. An International Journal of Educational Technology and Applied Linguistics, Vol. 38 (2).

Sulistyo, T. 2016. ICT in the EFL Speaking Classroom. The 4th LSCAC International Conference Proceeding.

UNESCO. 2002. Information and Communication Technology in Education. A curriculum for schools and a programme for Teacher Development. Paris: UNESCO. 